\title{
Sex, Sleaze, Slaughter, and Salvation: Phoren Tourists and Slum Tours in Calcutta (India)
}

\author{
University of Manchester
}

\begin{abstract}
This article explores the violence and voyeurism in viewing poverty in urban slums. By uncovering the social, economic, gendered, and racialized politics within a small-scale travel industry, I show how the latter cater to certain personal, sexual, and religious curiosities among a breed of travelers visiting developing countries. I did my ethnography in the slums of Calcutta, where travel entrepreneurs organized a range of discreet tours of ghettoes for white foreigners (primarily from Australia or the United States). These popular expeditions offered "sightings," such as half-naked women bathing at water tanks, ritualistic animal sacrifice, and neighborhoods for prostitutes. While reinforcing stereotypes of the primitive other (as opposed to the exotic other), these secret tours allowed travelers to indulge in a range of emotions, from real life voyeurism to "showing gratitude to God for being civilized." By emphasizing the ambivalences and contradictions in viewing and representing the other, this article argues further that the immoral and critical gaze of a small group of foreign tourists can affect the nature of morality and commercialism among large sections of the urban poor in India.
\end{abstract}

Keywords: anthropology, politics of poverty, sex tourism, slum moralities 


\section{Sex, Sleaze, Slaughter, and Salvation}

“ Where are no extra seats on the bus, you can't come today." I was pushed aside brusquely by Hari, 24, the main guide for the "sex and sacrifice" tours. I stood sulking at the door of a rundown bus parked at the edge of Toladanga, a slum in the heart of Calcutta. "We have a pick-up in front of the National Museum in fifteen minutes," said Hari, this time a little more kindly. "I can sit on the engine," I offered. "You like to watch the phoren (foreign) men?" Hari smirked at me. I smiled: "Some of them are nice." Hari sighed: "I watch the women at times. Hope we have some today. Okay, you're in.”

Tourists and tour operators, voyeurs and their service providers, did not enjoy being "observed" objectively by a professional researcher. Instead, the easiest access into this world of voyeurism was through the ethically challenging route of professing "personal curiosity" along with workrelated interests.

I perched myself gingerly on the engine, while Hari took a seat in front of the bus. Raju, 40, climbed into the driver's seat. Wiping his sweaty forehead with a cloth, he said, "The slum women were acting strange today. I told them to be at the water tank by 9:00 a.m. for the tourists to watch them bathe. They refused, and claimed they had other work. Your wife was also there, Hari. Are the women resisting?" Hari scowled and said, "It's not that we are asking the women to sleep with the male tourists. For that, we take the men to the prostitute bazaar. It's just business, and if I make some money, it also means a new sari for my wife."

Raju bowed his head before the steering wheel, murmured a prayer, and started the engine. The bus moaned and droned into life. The lacerated tires kicked up a storm of dust, and Calcutta, my natal home, flashed and flowed past the cracked windows. Growing up in a "better" neighborhood, nurtured by the protective environment created by my parents, my childhood and adolescence passed without any real knowledge about the city's underbelly. Anthropological forays into urban spaces that remain alien and peripheral to the world of middle/upper class city dwellers, however, have allowed me to uncover new dimensions of Calcutta. These encounters changed my perspective of metropolitan life, a state of being that I had experienced so differently even as a young adult.

A group of young tourists waited for us at the designated stop. "Welcome, welcome," shouted Hari in English. Some of them said, "Hiya," while others said, "Namashkar," while folding their hands. They trooped 


\section{Atreyee Sen}

into the bus, exchanged furtive glances, and fussed over sitting by the window. "Only two women passengers, not good for me, but you will have more fun," said Hari, winking at me while slamming shut the door of the bus. Pointing in my direction, he said, "She does research work in my slum, but today she is here to help with English translations." Thus, Hari explained away my presence and avoided "tourist suspicion," which could be damaging for his business. We were on our way.

This article explores the violence and voyeurism in slum tours of urban India. It offers a critique of anthropological writings that focus predominantly on conflictual relationships between tourists and locals. Instead of re-examining the slum as the new retreat of the rich, I argue that multifaceted tourist-local interactions implicates both parties in a struggle for cultural authenticity, religious and personal purity, commercial successes, place, and identity. My ethnographic landscape is Calcutta, a city in western India, which continues to capture the romantic and religious imagination of Western tourists. The contested urban landscape is marked by vast slum areas, where the land is a dense maze of make-shift shanties, squatter colonies, and fragile bamboo shelters, balanced precariously on poles over muddy swamps. Several scholars have tried to explain the fascination of the Calcutta slums, where the poor, "live on the edge, suspended over an abyss of uncertainty and bottomless poverty, the house on stilts a sad but apt metaphor for the vulnerabilities of their lives” (Roy 2002: 81). Hutnyk (1996), who studied the exploits of foreign backpackers in the city, argued that Calcutta's downfall as the capital of colonial India and its fame as the chosen home of Mother Teresa and her Missionaries of Charity led to a construction of the city as the hub of "poverty viewers." Unlike Hutnyk (1996), who explored the much larger travel world of foreign tourists, I focus on a small-scale, illegal, and secret travel industry, functioning out of the slums.

The "industry" comprised tiny offices in the ghettoes, no signboards, a group of local men dealing with the paperwork, phone calls, bookings, and cash transactions, the last preferably in foreign currency. The promotion strategy involved distributing pamphlets at the arrivals lounge of international airports, and giving out similar written promotion material at cheap hotels. "See sex and sacrifice in the City of Joy"1: the pamphlets were clear about the tour's agenda. The hotel owners, airport floor management authorities, and various others involved in this "game" were richly bribed and turned a blind eye to these activities. The tour operators organized dis- 


\section{Sex, Sleaze, Slaughter, and Salvation}

creet, but highly popular day excursions into the slum areas, which offered "sightings," such as half-naked women bathing at wells, ritualistic animal sacrifice, and ghettoes for prostitutes. Some of the scenes were staged or constructed by local slum-dwellers (such as women bathers); others were everyday rituals that were paraded as a spectacle (such as the slaughtering of goats and other small animals for religious purposes). The setting of the slum and the daily activities of slum-dwellers offered additional highlights to the tourists (such as women weavers at work with their knees akimbo). Most tour conductors feigned ignorance of the voyeuristic value of these "natural" sights.

My article uncovers emotional and economic strategies used by local sex businessmen to successfully cater to religious and sexual curiosities among certain phoren (and, in my ethnography, primarily Christian) travelers. While reinforcing stereotypes of the crude and coarse other (as against the exotic other), these secret tours allowed travelers to indulge in a range of sensations, from real-life voyeurism to "showing gratitude to God for being civilized.” By emphasizing the ambivalences and contradictions in viewing and representing the other, this article argues further that the immoral, often critical, gaze of a small breed of tourists affected shifting moralities and commercial ethics among large sections of the urban poor.

While my broader research focused on the construction of religious identities among poor women in Calcutta, my stray encounter with a "hidden away" travel enterprise peaked my interest. As a result, my ethnography for this article is rather complex. In the niche that I want to create for this article, I carry out a "mobile ethnography” of twenty-six bus tours, interviewing and observing everyone on board. However, in the first two sections of this article, I have used a single narrative to give the reader a flavor of a typical day on the bus. An elaborate sociology of the tourist communities (beyond age, sex, and nationality) is not explored in this article. Instead, I draw in the tour organizers, the bus drivers and conductors, the travelers and the objects of their interest, the privileged and the underprivileged within the same moral and fiscal economy. I argue that studies on small-scale, localized tourist industries need to move beyond the key "S" words of sex, sand, and sun, and explore voyeuristic interests in slaughter, sleaze, and salvation.

This article also highlights the unpredictability of field experiences for social anthropologists, and the ethical difficulties in writing about people's 


\section{Atreyee Sen}

encounters with voyeurism. Several scholars investigating cultures of violent voyeurism have tried to grapple with what Daniel (1997) refers to as the pornography in anthropological writing. Hansen, Needham, and Nichols (1989), while legitimizing limited trespassing in ethnography, suggest that the researcher could also split open and represent the field by bodily throwing him/herself into foreign, forbidden spaces inhabited by informants. In this article, I have made a bid to retain the authenticity of my accounts and capture the vitality and complexity of everyday life. I show that tourism as development, as leisure, and as generator of neo-economic and foreign policies (cf. Smith 1989; Urry 1990; Stanley 1998) are interlinked and implicated within an animated world of "sightseeing" that revolve around peddling poverty and primitiveness. I tell many stories: some voices are merely louder than the others. I have changed the names of my informants to protect their identities.

\section{Searching for Sleaze and Sex}

In order to understand the constitution of and dynamics within a slum, I will contextualize it briefly within patterns of rural-urban migration and subsequent intergenerational conflicts in aspiration and identities. Most of the slum dwellers in Toladanga were semi-literate, low caste, migrant farmers from nearby villages. The men, usually having lost their land or their agricultural produce, came to Calcutta with the hope of employment as construction workers, stock boys, laborers in various factories, and hand cart and rickshaw pullers. The unavailability of full-time work in these legal enterprises compelled many of them to seek out additional employment in semi-criminalized activities. The women usually followed the men as their cooks and cleaners, and later joined the peripheries of the unskilled labor economy to supplement the family income. Most families set up home by reclaiming marshy or abandoned land, and started out by building temporary shacks with bamboos and tarpaulin sheets. Over time, if the ground became stronger, those with more than meager resources built small, one-room houses. The younger children in the slums were usually born and brought up in the city. They viewed themselves as urban youth, and did not share the "I am dying to return and must return to die in the village" sentiment with their parents. They preferred their life of small-

JOURNEYS, VOL. 9 ISSUE $2 \mathbf{5 9}$ 


\section{Sex, Sleaze, Slaughter, and Salvation}

time jobs, neighborhood clubs, dabbling with local politics, and watching movies over farming and rearing cattle in the rural areas.

The first stop on the bus journey was the Toladanga slum. "Get the women ready," hissed Hari. Raju hurtled out of the bus and disappeared behind a wall of shanties. There was a tense pause, followed by a loud whistle. Hari smiled at the tourists and said, "Come along," in English. The "slum tourists" and I followed Hari through a maze of alleyways, plodding past rickety fencing, and peeping into feeble human habitation through creviced walls. The tourists quizzed Hari about sights, sounds, and smells that intrigued them. Our journey ended at the public water tank, where a group of twelve women scrubbed their bodies and washed their clothes with hard soap. Some of the women were nonchalant, while others glared angrily at the visitors. Jack, a tourist, rushed to the front of the crowd, and watched the women for several minutes. "What was so remarkable about this sight?" I asked him on our way back. He said:

It's great! These sweaty women take their saris off, and with a swift motion they lift their petticoats, and tie it on their chest! The petticoats bite into their flesh, and their heavy thighs are stretched on those flat stones around the well. When they pour water on themselves, the petticoats stick to their body. I did take a lot of pictures. Don't call me a pervert; this is better than watching nude white women washing themselves in fancy Western shower rooms, or even lounging around in bikinis by the pool. Men do this kind of thing, they watch women. But I am so tired of watching Western women. I enjoy this feeling of "raw"ness, because these women are not intending to look sexy or attract men. It's part of their daily routine, to bathe in the open.

The Internet, the easy availability of pornographic material, open prostitution, more overt practices of promiscuity, the supposedly effortless access to women's bedrooms and bathrooms had Jack "jaded." I rode along with more slum tourists who, like Jack, were "bored" with Western sexual practices, keenly pursuing new forms of Oriental eroticism. Visiting the land of the Kama Sutra did not mean temple tours of Khajuraho and viewing erotic stone carvings. For these groups of assorted sex tourists, sculptures of ancient sexual customs and conventions were creative, yet static and devoid of human vitality. The slum women in Calcutta, on the other hand,

60 JOURNEYS, VOL. 9 ISSUE 2 


\section{Atreyee Sen}

were vibrant. They did not appear to be overtly lustful. They were not displaying their sexuality, yet a glimpse of their bodies, their distinctive feminine dispositions, colors, textures of skin, desperation to maintain their bodily purity within a context of extreme poverty, supposedly separated everyday performances of poor women from most feminine worlds in the "West." I asked Pete, 24:

AS: Would you visit slums in the US and view poor women?

Pete: Nah! Poor women there would drink, smoke, be addicts, have shrunken faces, wear jeans, pierce their tongues, abuse you if you watched them or call you inside. The women here look so docile. They are obviously not protected by the local men, or by any law of the land!

The explicit performativity around the well stood in contrast to the surrounding life in the slum, where people negotiated tourists' attraction for more "natural" sights through overt acts of denial. While walking through the slums, several tourists would be fascinated by women workers with bare legs, some of them bending over while carrying a heavy load, some others swinging their hips while balancing water on their heads, and housewives squatting by the stoves or rearranging their saris. Initially, I believed that it was the eager gaze of the tourists that was a giveaway. Yet, during conversations with the tour operators, they claimed to be genuinely unaware of the voyeuristic value of the "non-staged" slum sights. This made me feel pensive, and I wondered why they could not perceive what had become so obvious to me. Over time, I felt that my own social conditioning was perhaps closer to a normalized elitist definition of womanhood, i.e., a "conservative," globalized, middle-class femaleness, which I could not fight in the field. Even though I felt culturally and linguistically closer to Bengali slum dwellers, the romantic mergers between the home and field had disappeared. I could easily envision what groups of voyeuristic "outsiders" could see.

However, scholars contributing to the anthropology of sex and desire, especially in the context of post-colonial south Asia, warn against naïveté. Osellas' study (1998) of flirting and friendship in Kerala and Chopra's analysis (2006) of male domestic workers in India reveal that the "pornography of everyday life" is not unnoticed by community members. The 


\section{Sex, Sleaze, Slaughter, and Salvation}

denial of knowledge about voyeurism may be related to maintenance and management of desires and public morality. In the Calcutta slums, the easy articulation of "we don't notice (amra tow dekhte paina)" was about reining in women's resistance. The slum men needed to convince the local women that the immoral gaze was restricted to the pavement around the water tank, and that it had not spilled over to pollute other areas and activities in the slums. By denying involvement in exhibiting other "sexual sights," the men precluded the possibility of women (such as Hari's wife) getting mobilized against the slum tours.

Erotic displays of feminine vulnerability did not interest some of the tourists. Several men eagerly awaited the second stopover in the "sex and slum" route. Shonagachi, thriving in the northern parts of the city, was an old, large, and notorious ghetto of sex workers. When the bus drove into the lanes of Shonagachi, the tourists were greeted loudly by a group of pimps drawn into this travel project. The latter caught hold of the arms and sleeves of as many men and women as possible, and dragged them off into various narrow alleys. Within Shonagachi, the tourists were allowed to walk freely under the guidance of local men. However, no one was allowed to stay behind for "fun." They were permitted to look around, take phone numbers of brothel owners, strike deals with the pimps, and also get maps and directions to the shanties of chosen sex-workers. The tour members had strict instructions to return to the bus after two hours.

Some slum tourists found "unconventional, unadulterated prostitution" to be a source of novelty. Philip, a tourist, said:

What I liked about Shonagachi is the absence of order, or any extra dressing to cater to Western tourists. Nothing is antiseptic. I take sex tours of southeast Asia. But prostitutes there have charts on their doors stating they are HIV negative. Also, they wear Western clothes, starve themselves to keep slim bodies for Westerners. Look at the women here. They are crude, fat, and ugly by any standards. There is nothing artificial about prostitution here. Even the pimps are brothers or children of prostitutes, and are wearing rags. Not the new-age pimps in suits, surrounded by their henchmen, like you get in the US and nowadays in Asia.

Several men spoke about new forms of "choice" in the flesh trade in Calcutta, which allowed them to play out different forms of racialized identi- 


\section{Atreyee Sen}

ties. For example, while doing sex tours in the United States or Australia, pimps rarely asked clients whether they wanted a low caste, high caste, untouchable, "chinky," Hindu, or Muslim woman. While a few tourists exercised choices to reinforce stereotypes about hierarchies within Indian society, others even related their desires to changing political climates in their own country. For example, Roger, a tourist, said, "I always wanted to sleep with a Muslim girl, especially after 9/11. Sleeping with the enemy you know! I just bargained in the bazaar for one."

What kind of impact did the sleaze and sex tours have on women tourists? All the women who I encountered on these sex tours remained certain that they had not embarked on these day journeys to transform the lives of poor women or develop feelings of sisterhood. Several tourists told me that they were more interested in viewing solicitous and sexual behavior by "other" women. After the viewings, however, most women found these desperate circumstances uncomfortable, and a few used the word "educational" to describe their experiences. Coming from a wealthy Catholic background (and living in the United States), Joanna had always met friends and family members who were "affluent and ignorant." They did not offer Joanna alternative perspectives on the contexts or condition of women in other parts of the world. "Money is numbing," she said. As a result of her sheltered upbringing, she felt no connection with God or "gratitude," which often made her parents unhappy. She journeyed to Calcutta to view the lives of impoverished women, and finally felt thankful for the life she had. "When I step into my bubble bath, I will think of the women by the tank, and instead of worrying about the temperature of the water, I will remember their misery," she said.

\section{Seeing Slaughter, Seeking Salvation}

The next spectacle on the tour involved a famous temple in Calcutta. This place of Hindu religious worship was very busy, and the main entrances were inevitably unapproachable, clogged with long queues of devotees, beggars, and the antics and activities of priests. Even though the temple remained open to non-Hindus, sex tourists, primarily Muslims and Christians, were strictly barred from areas marked for holy rituals. The temple was dedicated to a blood-thirsty goddess called Kali, and according to local 


\section{Sex, Sleaze, Slaughter, and Salvation}

Hindu ritualistic tradition, it was imperative that martial goddesses be appeased by animal sacrifice. Every alternate day, the priests would slaughter a goat at the temple altar, amid loud scriptural chanting, screaming and fainting disciples, and the acrid smoke of incense sticks and oil lamps. However, a slum area behind the temple provided entrance to a hidden spot from where people could observe the killings.

Initially, profits from the sex tours were insufficient to bribe the powerful priests and secure tourist admission into the site of animal sacrifice. However, disbarment reaped its own emotional benefits insofar as the clandestine character of the viewing dramatically increased the tourist's sense of anticipation during the walk to the enclosure. Cramped in the secret spot, all the bus passengers watched the slaughter, followed by the frenzy of devotees slipping and sliding on the animal blood. Several slum dwellers would dawdle around the enclosure with water and wet towels, in case the tourists fainted or needed (untrained) medical attention. The tour operators paid a hefty sum of money to these helpers, especially when the tourists had required assistance after a bout of vomiting. A number of tourists performed a parallel ritual of laughing, pointing and clapping during the sacrifice. Some of them sought affirmation that they had violated successfully the purity of a religious spot by their presence. Some expressed horror. Some felt sorry for the animals. Through all this excitement and confusion, however, the tour conductors unfailingly lay stretched on the ground and implored the goddess to forgive them for their immoral work. "We are driven by our empty stomachs, o mother (peter daye korte hocche ma)," they said, and remained uneasy about incurring the wrath of the violent goddess.

According to Ralph, a young tourist:

I am so glad that I am part of a civilized world, with a civilized religion. If any part of Christianity involved this kind of voodoo, I would not be a religious man. So, it's great to realize that your religion offers you an opportunity to be religious in an aesthetic way.

The final stop of the bus tour was a slum near Nimtola, the cremation site for Hindus in Calcutta. Poor families, who could not afford to take care of their elderly, discarded them on the borders of this slum. The aged were left on cots or mats to die of starvation. When they did die, the local municipal corporation truck carried the dead to the cremation site. At times, the

64 JOURNEYS, VOL. 9 ISSUE 2 


\section{Atreyee Sen}

more kindly slum dwellers carried the dead over to the Nimtola ghat (the bank of the Ganges river), where men in charge of funeral pyres (dom) would cremate the unidentified, abandoned corpses with leftover firewood and kerosene oil.

When the bus stopped near the slum, the tourists usually covered their faces with cloth at the sight of decaying flesh. They walked along the edge of the slum area surveying the sick and dying. Some tourists would bend over and chase away flies clinging to open sores. Others would leave packs of food next to the bony hands of the aged, not knowing that the latter were too weak to eat. After the tourists were gone, the local children would steal the food. Several slum dwellers gathered by the row of dying people. They said (in broken English), "You give money, we take care of old." A few tourists gave money, while others were suspicious that the slum dwellers would keep the cash. According to Nigel, a tourist, who did part with some money:

It's not a lot, like you are expected to give to big charities. This small act of giving cleans your soul, especially after having visited prostitute areas! I don't like Missionaries of Charity [an organization ran by Mother Teresa]. Some of my friends went there, and they were asked to feed people, and touch them. This is better. I gave them food, money, all from a distance. But I still did a good deed, I know where my money went and the condition of people who need it.

Even though a large section of the tourists used the last leg of the journey to achieve some form of salvation and cleansing of the soul, several others continued to use the tour of the dying as an arena for acknowledging and exerting cultural superiority. Janet, a tourist, had encounters with south Asians in diaspora who were assertively disapproving of certain "conventions" within Western families. She said:

So many people told me that there were no old age homes in India because the elderly, even among the poorest, were taken care of by the family. My non-Western friends made me feel so small because my grandparents lived in retirement homes. Now I know that 'my customs are better than yours' is all bullshit. Basically, people here abandon their aged to die. So, there is nothing extraordinary about Indian culture and their reverential attitude towards the aged.

JOURNEYS, VOL. 9 ISSUE $2 \quad \mathbf{6 5}$ 
Sex, Sleaze, Slaughter, and Salvation

\section{Changing Moralities, Changing Economies}

At sunset, the tour guides dropped a bunch of exhausted tourists in front of the National Museum. If I was around, we would shake hands. We thanked each other. One such evening, Hari, Raju, and I sauntered off to a tea shack for refreshments. "We have to bribe the policemen," reminded Raju. Hari looked downtrodden. "What if the women refuse again? We will lose customers," he said aloud. "Go talk to your wife," advised Raju.

We drove back to Toladanga slums, where we had started our journey. I went to Hari's house to get my bags, and his wife Nita looked cheerless. “Are you okay?” I asked. She looked out of the window wistfully and said, "Why are you encouraging these men?" She interpreted my non-interventionist, non-reprimanding stance as overt support to the slum tour operators. She and I sat down for a long dialogue, during which neighboring women joined us. I tried to explain my dilemmas as an academic, while the women confessed their fears. "Mothers, wives, sisters, and daughters" were coaxed, coerced, or cajoled into parading their nakedness by the slum water tank. The women feared that their polluted bodies and their tormented souls would "not even get a place in hell (norokeo sthan hobe na)." They were nostalgic for those times when their male guardians were protective and possessive, and saving women's honor and chastity was an unquestionable, established practice even within the slums. Extreme poverty had already eroded traditional ideas of female morality and mobility, primarily because women were compelled to enter the informal labor economy. However, displaying their bodies for Christian tourists was an extreme violation of religious, marital, and familial systems:

The Hindu slum men also watch us. But they get bored; they own us; they will get to see us at night. But these white men, they want to own us, but can't. Hence, they have heightened desires. We see it in their eyes. Yet we can’t stop because our own men don’t want us to stop.

Indeed, slum women felt dishonored when subjected to what they construed as the polluting tourist gaze. When trying to interpret how the foreign gaze generates an invented other, Orientalism seems to offer an apt theoretical framework. However, the indefinite transactions of the sex, sleaze, and slaughter market, the imperative of selling and the presence of

66 JOURNEYS, VOL. 9 ISSUE 2 


\section{Atreyee Sen}

men and women as Occidental buyers restricts its transferability in this context. Friedberg's (1998) gendered understanding of "the mobile, consuming gaze” is more useful. It adds specific meanings to exoticism and leads to varying constructions of Orientalism.

According to Friedberg (1998), men as consumers of the Orient are commercial, authoritative, and demanding. Women's spectatorship, on the other hand, is intimate, covertly related to personal transformation and unconcerned with sexual initiation (such as Joanna's new-found gratitude for privilege). In Calcutta, the tourist gaze within a small commercial domain recasts the Oriental woman as an object of desire or pity, and the Oriental landscape as rhetorically an erotic woman. However, I argue that the erotic and more authoritative colonizing imagination can only be explored in the context of urban poverty. Plush, comfort-oriented tourist packages and the globalized city dominated by supra-corporations limits the possibility of establishing difference and hierarchy, pursuing sexual fantasies and adventures, and discourages transgressive libidinal desire. Friedberg (1998) concludes that this desire to narrate an urban abroad, which is sexy and enticing, makes commercial uptakes and the reworking of city cultures inevitably exploitative.

Women's grievances against local tourism have also been part of a longstanding scholarly debate. Several anthropologists writing on gender and tourism argue that women often organize resistance against the presence of tourists in public/work places. Spurles (2006), for example, working on henna artisans in Morocco, shows that women workers clashed with local tourism operators over the former's organized aggression against strangers in public. The Moroccan women, however, continued to conform to normative feminine behavior in various other spatial arrangements, such as the home and places of religious worship. The nature of sex tourism in Calcutta was illegal, and the resistance offered by the slum women was aggressive, yet highly disorganized. Most of the women were scattered over different professions and skills. Some housewives were even persuaded to see themselves as economically productive, as displaying their bodies contributed indirectly towards the family income. The women were not unionized in any formal or informal sense, and received no support from the richly bribed police officials, government employees, and local politicians. The NGO workers working on “women's issues” remained skeptical about stepping beyond the parameters of their responsibilities. For example, most social workers stuck to dealing with domestic abuse or work-related 


\section{Sex, Sleaze, Slaughter, and Salvation}

exploitation. They would not challenge the men over sex tourism, preferring to stay within the legal confines of their job profiles.

The slum men, especially the ones who had cooperated to make the tours a success, cared for their profits. They were unemployed men with no professional training, mostly semi-illiterate, with little scope of finding jobs within the skilled or the unskilled labor market. For this group of men, a small-scale travel enterprise required low financial and labor investment. The income fed their families well, and also helped the men retain their fragile masculinities. Over the year that I worked in the Toladanga slum (where almost all the families became involved in providing support functions for these tours, ranging from serving tea to tourists to maintaining the travel buses), the men glorified themselves as providers. The demand for sex and sleaze allowed them to start illegal, yet profitable enterprises that did not involve direct drug dealing, gang affiliations, or violent encounters with the police. Also, these tours did not evolve in a social vacuum.

During the years before they started these excursions, the men earned an income by loitering around in hotels, selling marijuana to foreign tourists, and acting as pimps for various sex workers. They stumbled upon and, consequently, spent time learning about the changing needs and preferences of an assorted group of Western travelers. Their usual encounter was with what they termed as "harder" sex tourists, who independently fumbled their way through the flesh and death trade. These included drug and sex addicts, child molesters, homosexuals, more aggressive voyeurs, and "beach boy hunters." However, several slum men claimed that they also uncovered a growing range of "softer" travelers, who were keen to negotiate their own selves, sexualities, and racial identities through a more tempered engagement with poverty. The travel businesses were launched with the specific aim of exploiting the religious, economic, cultural, and sexual angst in these small groups of travelers journeying to Calcutta. The men persuaded the women in their homes, whether housewives or workers, to take part in their enterprise. Daily women's routines and activities were objectified and peddled to Western tourists, and this practice widened the rift between men's commercial activities and women's compromised honor in the slums.

Nava's investigation (2007) of visual cultures and imageries of the exoticized Orient shows how the growth of successful alien communities and the West's encounter with transnational cultures leads to what she describes as "the continuing instability of whiteness." The slum tours of

68 JOURNEYS, VOL. 9 ISSUE 2 


\section{Atreyee Sen}

Calcutta became a remarkably strategic response to certain contemporary "Western" cultural insecurities, where new forms of objectification reestablished racial differences and hierarchies.

The construction of "women's honor" in the slums, however, was ambiguous. There was quite a high level of promiscuity in Toladanga. Several women had long or short-term extra-marital affairs, which generated tensions among the men. Some unmarried or widowed women even traveled to other slum areas to visit their lovers. Many older women had flirtatious relationships with younger boys. Some maids had affairs with their male employers. The slum women were not even in camaraderie with sex workers in Shonagachi, who persevered to keep the lucrative sex tours running smoothly. If the survey of the water tank was left out of the tour agenda, sex tourism would not be contested by the slum women on the grounds of bodily commodification. Yet most of the slum women, the sinners and the saints, were angry and resentful about the tourist gaze. For the women, life on the urban fringes had made them flexible about their personal and religious morality, but only to an extent. It was the coercive nature of sex tourism, the pressure to negotiate with foreigners, and the loss of control over their own bodies that made women oppose their men. Women's honor was only superficially linked to dereliction of religious duties by men; women's real battle was to retain agency over making and asserting moral choices.

Burns (2004), who explored tourism in developing countries, comments that local politics often affects the construction of racial difference along the lines of power and contributes towards furthering distanciation between the West and the other. In the small-scale industry in Calcutta, the changing moralities of a mixed group of white visitors had an impact on the direction of the already changing moralities in the slums. Tourism was not the precursor. The allure of difference merely added to contradictory impulses within shifting aesthetic and libidinal economies in the local and transnational context. Thus, the slum women did not like being spoken for: their coerced visibility near the water tank was translated as an indirect ploy to contribute toward women's invisibility in the slums.

The strife between men and women had an impact on children in most families. Boys and girls from a smaller age group preferred to have food on their plates at the end of the day, and did not care much about their mothers' loss of dignity. "If my father and my mother both go to work, we get more rice, even an extra soap or lollipop," said Potol, 8. "But ma seems to 


\section{Sex, Sleaze, Slaughter, and Salvation}

be unhappy with that." Most teenagers had ambiguous positions. While some of the boys carelessly supported their mothers' or sisters' resistance to the tours, they also took pleasure in watching white women visiting their slums. Sometimes, they would harass the tourists for money, or try and sell them a range of products, from juice to jalebis to junk jewelry. They were keen to find out about various tour activities, enjoyed stories from the day's excursions, and, at times, felt ready to join the business. "It's better than heavy labor in a factory, with very low pay. You also like the work, don't you?" asked Jaga, 16. He was not enthusiastic to go to a regular school, and felt he would be better equipped to take on the challenges of this business by joining a course in "Learning English."

Some boys felt that "befriending" a white woman during these tours may even give them a passport to the West. Almost all the girls defended the older women's resistance, and were anxious about their futures by the water tank. "Do I also have to do that, father (amakeo ki korte hobe, baba)?" Ravi's fifteen-year-old daughter, Mala, asked him, after he had had an argument with his wife. Ravi looked over at Mala squatting by a mud stove, and said, "No. Your mother and I are doing this so that we can get you married off." "But ma is also married, and she still has to do it," complained Mala. Ravi appeared to be wracked with guilt, embarrassed that this exchange took place in front of me, and slipped into silence.

While Ravi was trying to create an intergenerational split in the familial moral codes, other slum men were keen to push younger women towards "water tank viewing." "It will offer a more attractive range," argued Moti, while "initiating" his sixteen-year old daughter into the 9:00 a.m. bathing ritual. The successes of sex tours were gradually splitting the families along gender lines: new moral and economic attitudes toward the tours were being recycled among the men, while the resistance and discomfort was passed on easily to young girls.

\section{Some Concluding Comments}

According to Wacquant (2004), ghettoes within a segregated urban landscape are hierarchically organized and symbolically constituted, invariably marked by struggles over a range of resources. A demand for new forms of tourist voyeurism and, consequently, the growing popularity of "dark 


\section{Atreyee Sen}

tourism" created a genre of service providers in the slums of Calcutta. This, in turn, led to a moral and commercial battle to give legitimacy to sex and slum tours. Most scholars on sex tourism highlight the ways in which international tourists view and exploit women's bodies in developing countries (Desmond 2000; Manderson and Jolly 1997; Rao 1999). There is also an amount of literature that explores the role of local men in encouraging sex tourism (Ryan and Hall 2001; Brennan 2004; Truong 1982).

The landscape of death and poverty, the spectacle of religious rituals and superstition, the bodies of poor women, and the pimps and the prostitutes became "resources," on the basis of which better profits could be accrued for both the tourists and slum dwellers. The tour was representative of new forms of gendered structural violence in the slums, whereby the identities of men expelled from the "regular" urban economy became more and more fractured; as they would rather be immoral and providers for their family than be poor and protectors of women. What makes the scenario in the Calcutta slums unique is how younger boys also wanted to develop expertise to sustain the tourism industry, rather than inherit traditional roles as guardians of women. Beyond "respectability," the successes of the small-scale industry became increasingly dependent on gendered power hierarchies in the slums and, of course, the heterosexual tourist gaze.

There are various implications of this sex and slaughter tourism in south and southeast Asia, and the attractiveness of these tours become indicative of some global changes in tourist "traditions." My research draws attention to the ways that tourists are lured toward, actively seek, or stumble across poverty, people, and practices. It may mark the declining popularity of historical and heritage sites. For example, in a recently published study titled, Is Tourism Destroying the Angkor Wat? (2007), government officials and the tourism department in Cambodia have expressed concern over fewer tourists arriving at Angkor Wat. It states, "More tourists prefer smaller towns and villages, and excitedly crowd around local rituals, such as shamans swallowing beating snake hearts” (2007: 45). So, the question remains: what are the material objects, human performances, and physical sensations sought after by new-age tourists? Is it the experience of physical and mental repulsion, the excitement of breaking taboos, the proximity or contact with the bodies of others, the embodied sensations of collective clapping and vomiting, or the shock of extreme difference as sheer pleasure? 


\section{Sex, Sleaze, Slaughter, and Salvation}

According to Haldrup and Larsen, "Emblematic tourist performances involve, and are made possible and pleasurable by objects, machines and technologies" (2006: 278). In case of the Calcutta slums, the staged and non-staged spectacles were attracting a group of individuals who were not just keen to explore the cuisine, the clubs, and the colonial structures of central Calcutta, but also wanted a "see-but-not-touch," less hazardous, guided and guarded engagement with poverty, which could not be obtained through standard, government-approved, legal channels of tourism. While the tour operators felt that they were in control of these excursions, because they disallowed sexual contact with their own women, the tourists emphasized their own agency in regulating interracial sexual relations and communications. Thus, these tours can be more easily re-interpreted as forms of ethnic and imperial tourism, and, as suggested by Nash (1996), they offer a form of tourist/host interaction that impacts and transforms both parties. The Calcutta slums were marked by the presence of sex tourists with "no expectations of hospitality or leisure, just viewing the other, not about exploding stereotypes, but about re-affirming it" (Crick, 1989: 311), where the tourists and the locals reinforced myths and labels about each other. In addition to highlighting the tensions between the tourists and the locals, this article also shows how slum men, women, and tourists are all caught up in a conflict over identity, religion, morality, changing sexualities, and economic opportunities.

The presence of this travel industry had also turned the slum into a site of new struggles. Secret tourism had impacted gender dynamics in most families, and battles arose over spatial resistance. By polluting religious places by their mere presence, and violating poor women's bodily purity by their gaze, the tourists often believed that they were corrupting sacred spaces within the local socio-normative structures. The women bathers, on the other hand, were resisting that violation, while trying to reclaim a public water tank as their private space. The insider-outsider, tourist-local dynamics had also changed. Slum women claimed that local men had become "outsiders" by conspiring with foreigners. For the tourists, "outsideness" remained undisputed, although, perhaps at certain moments, they felt like insiders by virtue of their inclusion in the "authentic" experience of slum life.

When I left the slums, the tour operators were busy expanding their schemes and coordinating with various other poverty-riddled areas to keep 


\section{Atreyee Sen}

their businesses afloat. In one political constituency, the police clamped down on the trade. The gossip-mongers in Toladanga told me that the officer in charge of the local police station had fallen in love with a school teacher, who often gave free lessons to slum children. The officer wanted the slum to be a "clean" place for her regular visits. "He did not even return the bribe we paid him," the operators complained. In other areas, slum families were sending off their elderly for display when there was a shortage of dying people for tourist viewing. I was sad to leave Raju and Hari. The three of us had become friends and followers. Raju got electricity in his house from the tour profits. His wife and children seemed happy. Hari's wife, on the other hand, refused to cook and clean for him. She did not light a stove or even a lamp after dark. It was evening when I was saying my goodbyes, and I turned to look at two little shanties where I had once received a lot of hospitality. One home was glowing, while the other was shrouded in darkness.

\section{Acknowledgment}

I would like to thank Caroline and Filippo Osella, Nilanjan Sarkar, Gillian Evans, and members of the Anthropology Department at Brunel University, especially James Staples, for their valuable comments on this article.

\section{Notes}

1. Dominique Lapierre, an international journalist, wrote an impressionistic novel on death, disease, and hope in the Calcutta slums. The book, City of Joy, became the travel bible of most tourists journeying into Calcutta.

JOURNEYS, VOL. 9 ISSUE $2 \mathbf{7 3}$ 
Sex, Sleaze, Slaughter, and Salvation

\section{References}

Brennan, Denise. 2004. What's Love Got to Do With It? Transnational Desires and Sex Tourism in the Dominican Republic. Durham, NC and London: Duke University Press.

Burns, Peter. 2004. "Tourism Planning a Third Way." Annals of Tourism Research 31, no. 1: 24-43.

Chopra, Radhika. 2006. "Invisible Men: Masculinity, Sexuality, and Male Domestic Labor.” Men and Masculinities 9, no. 2: 152-167.

Crick, Malcolm. 1989. "Representations of International Tourism in the Social Sciences: Sun, Sex, Sights, Savings, and Servility.” Annual Review of Anthropology, October, vol. 18: 307-344.

Daniel, Valentine. E. 1997. Charred Lullabies: Chapters in an Anthropography of Violence. Princeton: Princeton University Press.

Desmond, Jane C. 2000. Staging Tourism: Bodies on Display from Waikiki to Sea World. Chicago: University of Chicago Press.

Friedberg, Anne. 1998. "The Mobilized and Virtual Gaze in Modernity: Flaneur/Flaneuse.” Pp. 253-262 in The Visual Culture Reader, ed. N. Mirzoeff. London and New York: Routledge.

Haldrup, Michael, and Jonas Larsen. 2006. "Material Cultures of Tourism.” Leisure Studies 25, no. 3: 275-289.

Hansen, C., C. Needham and B. Nichols. 1989. "Skin Flicks: Pornography, Ethnography and the Discourses of Power." Discourse 11, no 2: 64-80.

Hutnyk, John. 1996. The Rumour of Calcutta: Tourism, Charity and the Poverty of Representation. London: Zed Books.

Manderson, Lenore, and Margaret Jolly (eds.). 1997. Sites of Desire/Economies of Pleasure: Sexualities in Asia and the Pacific. Chicago: University of Chicago Press.

Nash, Dennison. 1996. Anthropology of Tourism. New York: Pergamon.

Nava, Mica. 2007. Visceral Cosmopolitanism: Gender, Culture and the Normalisation of Difference. Oxford: Berg.

Osella, Caroline, and Filippo Osella. 1998. "Friendship and Flirting: Micro-Politics in Kerala, South India.” The Journal of the Royal Anthropological Institute. 4, no. 2: 189-206.

Rao, Nina. 1999. "Sex Tourism in South Asia." International Journal of Contemporary Hospitality Management 11, no. 2/3: 96-99.

74 JOURNEYS, VOL. 9 ISSUE 2 


\section{Atreyee Sen}

Roy, Ananya. 2002. City Requiem, Calcutta: Gender and the Politics of Poverty. Minneapolis: University of Minnesota Press.

Ryan, Chris, and Michael Hall. 2001. Sex Tourism: Marginal People and Liminalities. London and New York: Routledge.

Smith, Valentine (ed.). [1977] 1989. Hosts and Guests: The Anthropology of Tourism. Philadelphia: University of Pennsylvania Press.

Spurles, Patricia. 2006. "Women, Gender, and Tourism: Morocco." in Encyclopaedia of Women and Islamic Cultures, vol. 4, ed. S. Joseph, Leiden: Brill Academic Publishers.

Stanley, Nick. 1998. Being Ourselves for You: The Global Display of Cultures. London: Middlesex University Press.

Truong, T.D. 1982. "The Dynamics of Sex Tourism.” Development and Change 14, no. 4: 533-553.

Urry, J. 1990. The Tourist Gaze: Leisure and Travel in Contemporary Societies. London: Sage Publications.

Wacquant, Loic. 2004. "Decivilising and Demonising: Remaking the Black American Ghetto and Elias in the Dark Ghetto.” Pp 95-121 in The Sociology of Norbert Elias, ed. Steven Loyal and Stephen Quilley, Cambridge: Cambridge University Press. 